\title{
Folate Binding Protein J65 Peptide Vaccine
}

National Cancer Institute

\section{Source}

National Cancer Institute. Folate Binding Protein 165 Peptide Vaccine. NCI Thesaurus. Code C113660.

A cancer vaccine comprised of human leukocyte antigen (HLA)-A2-restricted folate binding protein (FBP) epitope 165 ( 9 amino acids; EIWTFST KV), with potential immunostimulatory and antineoplastic activities. Upon intradermal injection, FBP J65 peptide vaccine may induce a specific cytotoxic T-lymphocyte $(C T L)$ response against $J 65$ FBP-expressing tumor cell types. FBP is a membrane-bound, tumor-associated antigen overexpressed in various tumor types, including breast, ovarian and endometrial cancers. J65 is a strongly immunogenic peptide. 